\title{
AIMED CONTROL OF THE FREQUENCY SPECTRUM OF EIGENVIBRATIONS OF ELASTIC PLATES WITH A FINITE NUMBER OF DEGREES OF MASS FREEDOM BY INTRODUCING ADDITIONAL GENERALIZED KINEMATIC DEVICES
}

\author{
Pavel A. Akimov ${ }^{1,2}$, Leonid S. L yakhovich ${ }^{2}$ \\ ${ }^{1} \mathrm{~N}$ ational Research M oscow State University of Civil Engineering, M oscow, RUSSIA \\ ${ }^{2}$ Tomsk State U niversity of A rchitecture and B uilding, Tomsk, RUSSIA
}

\begin{abstract}
As is known, targeted regulation of the frequency spectrum of natural vibrations of elastic systems with a finite number of degrees of mass freedom can be performed by introducing additional generalized constraints and generalized kinematic devices. Each targeted generalized constraint increases, and each generalized kinematic device reduces the value of only one selected natural frequency to a predetermined value, without changing the remaining natural frequencies and all forms of natural vibrations (natural modes). To date, for some elastic systems with a finite number of degrees of freedom of masses, in which the directions of mass movement are parallel and lie in the same plane, special methods have been al ready developed for creating additional constraints and generalized kinematic devices that change the frequency spectrum of natural vibrations in a targeted manner. In particular, a theory and an algorithm for the creation of targeted generalized constraints and generalized kinematic devices have been developed for rods. It was previously proved that the method of forming a matrix of additional stiffness coefficients, specifying targeted generalized constraint, in the problem of natural vibrations of rods can also be applied to solving a similar problem for elastic systems with a finite number of degrees of freedom, in which the directions of mass movement are parallel, but do not lie in the same plane. In particular, such systems include plates. The distinctive paper shows that the method of forming a matrix for taking into account the action of additional inertial forces, specifying targeted kinematic devices in the problem of natural vibrations of rods can also be applied to solving a similar problem for elastic systems with a finite number of degrees of freedom, in which the directions of mass movement are parallel, but do not lie in the same plane. However, the algorithms for the creation of targeted generalized kinematic devices developed for rods based on the properties of rope polygons cannot be used without significant changes in a similar problem for plates. The method of creation of computational schemes of kinematic devices that precisely change the frequency spectrum of natural vibrations of elastic plates with a finite number of degrees of mass freedom is a separate problem and will be considered in a subsequent paper
\end{abstract}

Keywords: natural frequency, natural mode, targeted generalized constraint, targeted generalized kinematic device, stiffness coefficients, inertial forces

\section{ПРИЦЕЛЬНОЕ РЕГУЛИРОВАНИЕ СПЕКТРА ЧАСТОТ СОБСТВЕННЫХ КОЛЕБАНИЙ УПРУГИХ ПЛАСТИН С КОНЕЧНЫМ ЧИСЛОМ СТЕПЕНЕЙ СВОБОДЫ МАСС ПУТЁМ ВВЕДЕНИЯ ДОПОЛНИТЕЛЬНЫХ ОБОБЩЕННЫХ КИНЕМАТИЧЕСКИХ УСТРОЙСТВ}

\author{
П.А. Акимов ${ }^{1,2}$, Л.С. Ляхович ${ }^{2}$ \\ ${ }^{1}$ Национальный исследовательский Московский государственный строительный университет, \\ г. Москва, РОССИЯ \\ ${ }^{2}$ Томский государственный архитектурно-строительный университет, г. Томск, РОССИЯ
}

Аннотация: Известно, что прицельное регулирование спектра частот собственных колебаний упругих систем с конечным числом степеней свободы масс может выполняться введением дополнительных 
обобщённых связей и обобщённых кинематических устройств. Каждая обобщённая прицельная связь увеличивает, а каждое обобщённое кинематическое устройство уменьшает величину лишь одной выбранной собственной частоты до наперёд заданного значения, не изменяя при этом остальные собственные частоты и все формы собственных колебаний. К настоящему времени для некоторых упругих систем с конечным числом степеней свободы масс, у которых направления движения масс параллельны и лежат в одной плоскости, разработаны методы создания дополнительных связей и обобщённых кинематических устройств, прицельно изменяющих спектр частот собственных колебаний. В частности, для стержней разработаны теория и алгоритмы формирования прицельных дополнительных связей и обобщённых кинематических устройств. Ранее было доказано, что метод формирования матрицы дополнительных коэффициентов жесткости, характеризующих прицельную связь, в задаче о собственных колебаниях стержней, может быть применен и при решении аналогичной задачи для упругих систем с конечным числом степеней свободы, у которых направления движения масс параллельны, но не лежат в одной плоскости. В частности, к таким системам относятся пластины. В данной статье показано, что метод формирования матрицы учета действия дополнительных инерционных сил, характеризующих прицельное кинематическое устройство, в задаче о собственных колебаниях стержней, может быть применен и при решении аналогичной задачи для упругих систем с конечным числом степеней свободы, у которых направления движения масс параллельны, но не лежат в одной плоскости. Однако, алгоритмы формирования прицельных обобщённых кинематических устройств, разработанные для стержней на основе свойств верёвочных многоугольников, не могут быть без существенных изменений использованы в аналогичной задаче для пластин. Метод формирования расчётных схем кинематических устройств, прицельно изменяющих спектр частот собственных колебаний упругих пластин с конечным числом степеней свободы масс, представляет собой отдельную задачу и будет в рассмотрен в последующей работе

Ключевые слова: частота собственных колебаний, форма собственных колебаний, обобщенная прицельная дополнительная связь, обобщенное прицельное кинематическое устройство, коэффициенты жесткости, инерционные силы

\section{INTRODUCTION}

When designing structures, in some cases it becomes necessary to deduce one or several natural frequencies from a certain frequency interval. As is known [1-4] one of the methods for solving such a problem is the creation of targeted generalized constraints and generalized kinematic devices. Special methods and algorithms of creation of generalized constraints and generalized kinematic devices for elastic rods carrying a finite amount of concentrated masses were developed and presented in the abovementioned papers. It was shown in [5] that the method of forming a matrix of additional stiffness coefficients, specifying the targeted constraints in the problem of natural vibrations of rods can also be applied to solving a similar problem for elastic systems with a finite number of degrees of freedom, in which the directions of motion of the masses are parallel, but do not lie in the same plane. Let us show in the distinctive paper that a similar approach can be applied to solving the problem of creating targeting generalized kinematic devices for elastic sys- tems with a finite number of degrees of freedom, in which the directions of motion of the masses are parallel, but do not lie in the same plane. In particular, such systems include plates. By analogy with the approach, described in [5], let us firstly present a method of creation of targeted kinematic devices for elastic rods [6] carrying a finite amount of concentrated masses. We can use system shown in Figure $1[3,4]$.

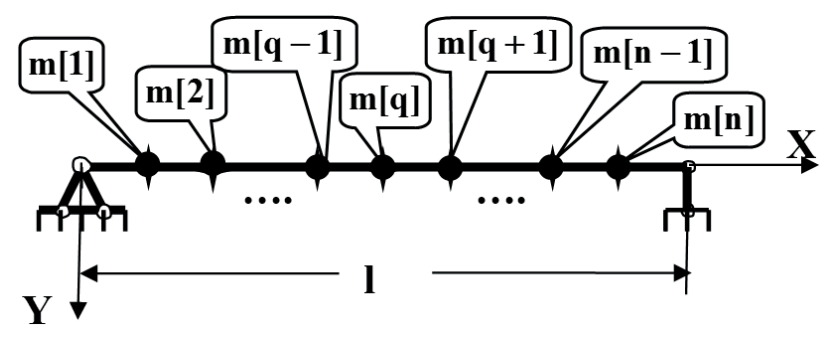

Figure 1. Sample system.

As in [5], the main system of the displacement method was chosen (Figure 1b). The equations of the displacement method were written in the form conventional for systems with a finite number of degrees of freedom 


$$
\begin{aligned}
& \left(r[1,1]+m[1] \omega^{2}\right) v[1, j]+r[1,2] v[2, j]+\ldots+r[1, q] v[q, j]+\ldots+r[1, n] v[n, j]=0 \\
& r[2,1] v[1, j]+\left(r[2,2]+m[2] \omega^{2}\right) v[2, j]+\ldots+r[2, q] v[q, j]+\ldots+r[2, n] v[n, j]=0
\end{aligned}
$$

$r[n, 1] v[1, j]+r[n, 2] v[2, j]+\ldots+r[n, q] v[q, j]+\ldots+\left(r[n, n]+m[n] \omega^{2}\right) v[n, j]=0$

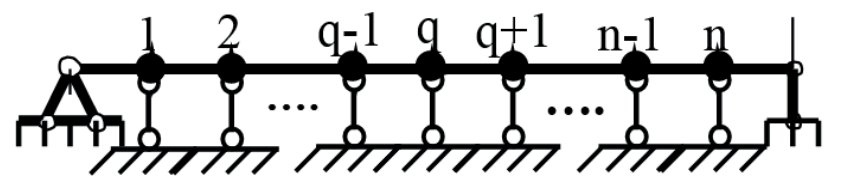

Figure 2. M ain system of the displacement method (sample).

Values $r[i, k]$ in (1) form matrix of stiffness coefficients $A=\|r[i, k]\| ; m[i]$ are the values of the masses, which form a diagonal matrix $M=\|m[i]\| ; \omega$ is the frequency of natural vibrations of the system; $v[k, j]$ are displacements in the direction of motion of the masses in the $j$ th form of natural vibrations (natural modes). Roots of the equation

$$
\left|A-\omega^{2} M\right|=0
$$

determine the spectrum of frequencies of natural vibrations of the system

$$
\omega[1], \omega[2], \ldots, \omega[q-1], \omega[q], \omega[q+1], \ldots \omega[n] .(3)
$$

For example, in $[3,4]$ for rods it is shown that a kinematic device with one degree of activity transfers to the structure a generalized targeted inertial force, which reduces the value of only one natural vibration frequency to a given value, leaving the rest of the spectrum frequencies unchanged. The device is formed on the basis of a matrix for taking into account the action of additional inertial forces

$$
M_{0}=M_{m 0} M_{m},
$$

where we have

$$
M_{m}=\| m_{0}\left[i, k \|_{i, k=1}^{n} .\right.
$$

The matrix $\mathrm{M}_{0}$ must have special properties. If the introduced kinematic device is targeted at the $q$-th natural frequency, then the coefficients of the matrix $M_{m}\left(\left\|m_{0}[i, k]\right\|_{i, k=1}^{n}\right)$ should be orthogonal to the coordinates of the modes of natural vibrations of the remaining frequencies of the spectrum. That is we have

$$
\begin{aligned}
& \sum_{k=1}^{n} m_{0}[i, k] v_{\omega}[k, j]=0, \\
& \quad(i=1,2, . ., n, j=1,2, . ., q-1, q+1, . ., n) .
\end{aligned}
$$

With respect to the $q$-th natural frequency, which is "targeted" by the kinematic device we have

$$
\sum_{k=1}^{n} m_{0}[i, k] v[k, q] \neq 0, \quad(i=1,2, \ldots, n) .
$$

It was shown in $[3,4]$ that conditions (6) and (7) will be satisfied by the coefficients

$$
m_{0}[i, k]=m[i] m[k] v_{\omega}[i, q] v_{\omega}[k, q] \text {. }
$$

The value of the factor $M_{m o}$ is found as the root of the equation

$$
\left|\left(A-\omega_{s}^{2} M\right)-M_{m 0}\left(\omega_{s}^{2} M\right)\right|=0 .
$$

Considering that the $(q)$-th form of natural vibrations remains its form of natural vibrations even at frequency $\omega_{s}$, the factor $M_{\text {mo }}$ can be found as 


$$
=\frac{\sum_{i=1}^{n} \sum_{k=1}^{n}\left(a[i, k]-\omega_{s}^{2} m[i, k]\right) v_{\omega}[i,(q)] v_{\omega}[k,(q)]}{\sum_{i=1}^{n} \sum_{k=1}^{n} \omega_{s}^{2} m_{0}[i, k] v_{\omega}[i,(q)] v_{\omega}[k,(q)]} .
$$

The result of solving the equation

$$
\left|A-\omega^{2}\left(M+M_{m 0} M_{m}\right)\right|=0 .
$$

must confirm that the modes of natural vibrations have not changed, and the "targeted" frequency has decreased to $\omega_{\mathrm{s}}$.

The kinematic device, which will correspond to the matrix of coefficients for taking into account the action of additional inertial forces

$$
M_{0}=M_{m 0} M_{m} \text {, }
$$

where $M_{m}=\| m_{0}\left[i, k \|_{i, k=1}^{n}\right.$,

should provide the ratio between the nodal displacements the same as between the coordinates of the $q$-th form of natural vibrations of the original system. In $[3,4]$ it is also shown that such a relation will be realized if the kinematic device transfers inertial forces to the nodes, the ratios between which will be proportional to the ratios between the forces

$$
R_{0}[i]=m[i] v_{\omega}[i, q]
$$

A n example of such a generalized targeted kinematic system for a rod is a sprengel, the outline of which is determined by a rope polygon built in the plane of motion of masses by forces (see, for example, $[3,4])$.

The derivation of the expressions for the coefficients of the matrix for taking into account the action of additional inertial forces (4) for the rods is based on the use of the displacement method in the conventional form and the properties of the modes of natural vibrations (natural modes).
Since the modes of natural vibrations of the plates, as well as for rods, are orthogonal, the problem for elastic plates carrying a finite number of concentrated masses, as well as for rods, will be based on the formation of a matrix for taking into account the action of additional inertial forces. The coefficients $\left\|m_{0}[i, k]\right\|_{i, k=1}^{n}$ must also satisfy conditions (6) and (7) and be determined by dependencies (8).

Let us give an example that confirms that the matrix of additional stiffness coefficients (4) serves as the basis for creating targeted kinematic devices and for elastic plates carrying a finite number of concentrated masses.

Let us consider a plate from [5], carrying 25 concentrated masses (Figure 3).

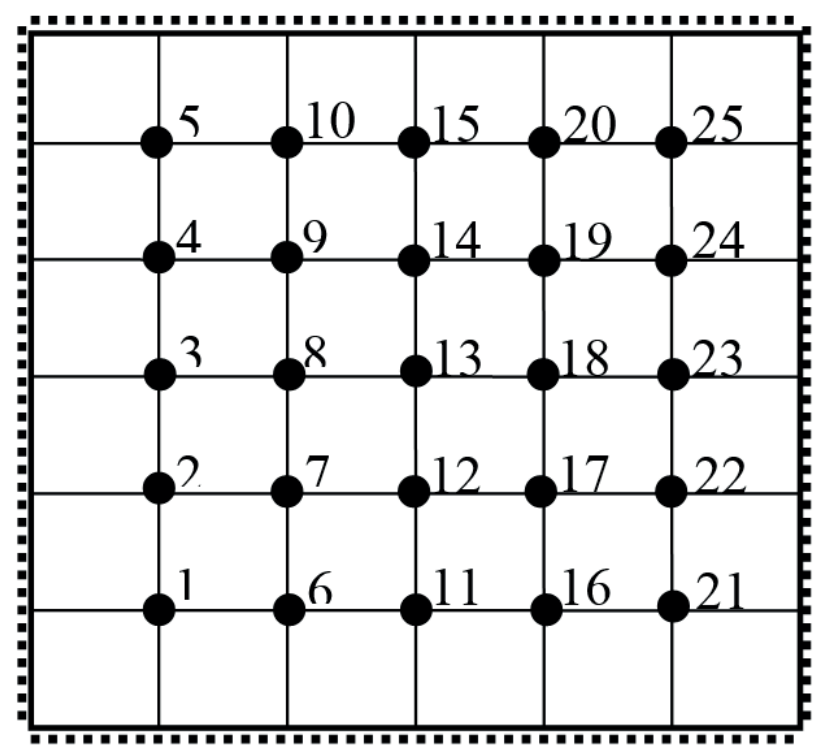

Figure 3. Considering plate (sample).

In node number 9 the mass is equal to $600 \mathrm{~kg}$, in node number 18 the mass is equal to $1000 \mathrm{~kg}$, and in other nodes the mass is equal to $800 \mathrm{~kg}$ each. The dimensions of the plate in the plan are $6 \mathrm{~m}$ by $6 \mathrm{~m}$, the thickness is equal to $0.12 \mathrm{~m}$. The modulus of elasticity of the plate material is $E=24,000,000,000 \mathrm{n} / \mathrm{m} 2$ Poisson's ratio is equal to $v_{0}=0.2$. With the main system of the displacement method (Figure 4) and onedimensional numbering of values $v[k, j]$ in accordance with Figure 3, the spectrum of natural vibration frequencies is determined as the roots of equation (2). 


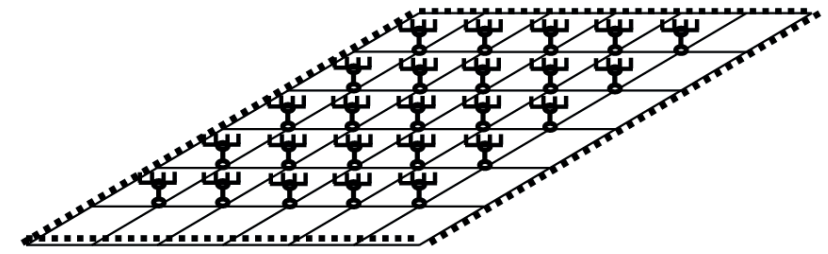

Figure 4. M ain system of the displacement method (sample).

The values of the first five frequencies of natural vibrations of the plate and the coordinates of the corresponding eigenmodes are given in Table 1 (columns are initial frequencies and shapes).

Suppose that it is required to expand the interval between the fourth and fifth natural frequencies by reducing the value of the fourth frequency from $146.834 \mathrm{sec}^{-1}$ to $110 \mathrm{sec}^{-1}$. For this, in accordance with (6), (7) and (8), we can form a matrix of the matrix for taking into account the action of additional inertial forces. The data required for using dependencies (6), (7) and (8) are given in the description of the plate and in Table 1 (columns are initial frequencies and shapes).

A fter the formation of the matrix of the action of additional inertial forces, taking into account their influence, we determine from equation (11) the modified spectrum of natural frequencies and the corresponding vibration modes.

The first five natural frequencies and their corresponding shapes are shown in Table 1 (columns are modified frequencies and shapes).

It can be seen from Table 1 that taking into account additional stiffness coefficients did not change any of the modes of natural vibrations of the plate, but only reduced the value of one of the frequencies from $146.834 \mathrm{~s}^{-1}$ to a given value of $110 \mathrm{~s}^{-1}$. This result clearly illustrates the possibility of using dependencies (6), (7) and (8) for solving the problem of a generalized kinematic device of constraints for elastic plates with a finite number of degrees of freedom of masses.

The generalized kinematic device for the plate, as well as for the rod, must create an additional generalized inertial force that ensures the target of the action.
As noted above, the properties of the kinematic devices for the rods are based on the properties of the natural vibration modes. The same properties apply to elastic plates. This circumstance serves as a justification for using the results of formulating the properties of kinematic devices for rods and in a similar problem for plates.

Thus, for an elastic plate with a finite number of degrees of freedom of masses, the generalized kinematic device must correspond to the matrix for taking into account additional inertial forces (4). If the computational scheme of the constraint is represented by a variant of the hingerod system, then it should be with one degree of activity, in the nodes of the plate where the masses are located, racks are installed in the direction of movement of the masses, and during oscillations in the racks of the system, forces should arise, the ratios between which are proportional to the ratios between efforts $R_{0}[i]$ (12). In this case, in the structure of the constraint there should not be any connections with the plate, except for the racks installed in the nodes of the plate, where the masses are located. So, in this paper it is shown that the method of forming the account of additional inertial forces that determine the targeted kinematic device in the problem of natural vibrations of rods can also be applied to solving similar problems for elastic systems with a finite number of degrees of freedom of masses, for which the directions of motion of masses parallel, but not in the same plane.

The paper substantiates and formulates the properties and requirements to which the design schemes of targeted kinematic devices in the problem under consideration must correspond.

Design schemes of generalized kinematic devices that meet the above requirements are multivariate and depend on the shape of the plate, the locations of the masses and some other features of the original object. Taking these circumstances into account, the approaches and algorithms for the formation of the corresponding design schemes that purposefully change the spectrum of natural vibration frequencies of elastic plates with a finite number of degrees of freedom of masses represent a separate problem and will be considered in a subsequent work. 
Table 1. Results of analysis.

\begin{tabular}{|c|c|c|c|c|c|c|c|c|c|c|}
\hline & \multicolumn{5}{|c|}{ Initial frequencies and modes } & \multicolumn{5}{|c|}{ M odified frequencies and modes } \\
\hline$\omega$ & 6.6583 & 91.0084 & 92.7466 & 146.834 & 178.911 & .6583 & 91.0084 & 92.7466 & 110.0000 & 178.911 \\
\hline 1 & 0070 & & & & & & & & & 1547 \\
\hline 2 & & & & & -0.0063 & & & & & .0063 \\
\hline 3 & & 68 & & & .1657 & 649 & & & & .1657 \\
\hline 4 & 20 & 14 & & 0. & -0.0063 & 420 & 514 & & & 0.0063 \\
\hline 5 & 0818 & 0579 & 71 & 0.26 & 0.1548 & .0818 & 579 & & -0.2624 & 0.1548 \\
\hline 6 & 441 & 2533 & & -0.2517 & 0.2788 & 1441 & 533 & 398 & 0.2517 & 0.2788 \\
\hline 7 & 492 & 3484 & & -0.2447 & 0.0003 & 2492 & 3484 & 840 & 0.2447 & 0.0003 \\
\hline 8 & $\overline{7}$ & 1 & & 0.0 & -0.2788 & & & & & -0.2788 \\
\hline 9 & & & & & & & & & & \\
\hline 10 & & 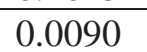 & & 0. & & 3 & & & 642 & 89 \\
\hline 11 & & & & & & & & & 58 & 359 \\
\hline 12 & & & & & & 395 & & & 17 & .0088 \\
\hline 13 & 3336 & 0082 & & 0.0 & -0.3237 & 3336 & 082 & & -0.0070 & -0.3237 \\
\hline 14 & 2877 & 1313 & & & 0.0088 & 0.2877 & & & -0.0124 & 0.0088 \\
\hline 15 & 1657 & -0.1331 & 505 & 0.0 & 0.3359 & 1657 & & & -0.0131 & 0.3359 \\
\hline 16 & 0.1454 & 0.0007 & & & 0.3025 & 54 & 007 & 856 & -0.2417 & 0.3025 \\
\hline 17 & & & & & & & & & -0.2415 & 0.0119 \\
\hline 18 & & & & & & & & & & -0.2941 \\
\hline 19 & & & & & & & & & & 0118 \\
\hline 20 & & 98 & & & 0.3025 & 46 & & & 432 & 3025 \\
\hline 21 & & & & & & & & & 437 & .1811 \\
\hline 22 & & -0.1445 & & & 0.0151 & 461 & & 454 & -0.2416 & 0.0151 \\
\hline 23 & 0.1688 & -0.2486 & & -0.0059 & -0.1580 & 1688 & & 1349 & 0.0059 & -0.1580 \\
\hline 24 & 1457 & -0.2827 & 35 & -0.2517 & 0.0151 & 0.1457 & 0.2827 & & 0.2517 & 0.0151 \\
\hline 25 & 0838 & -0.1910 & 633 & -0.2494 & 0.1811 & 0.0838 & 0.1910 & 0.0633 & 0.2494 & 0.1811 \\
\hline
\end{tabular}

\section{REFERENCES}

1. Nudelman Ya.L., Lyakhovich L.S., Giterman D.M. 0 naibolee Podatlivyh Svjazjah Naibol'shej Zhestkosti [A bout the M ost $Y$ ielding Constraints of the Greatest Rigidity]. // Problems of Applied Mechanics and $M$ athematics, Tomsk, TSU Publishing H ouse, 1981, pp. 113-126 (in Russian).

2. Giterman D.M., Lyakhovich L.S., Nudelman Ya.L. Algoritm Sozdanija Rezonansno-bezopasnyh Zon Pri Pomoshhi Nalozhenija Dopolnitel'nyh Svjazej [Algorithm for Creating Resonance-Safe Zones by Imposing A dditional Constraints]. // Dynamics and Strength of $M$ achines, $V$ ol. 39, K harkov, "V ishcha Schkola", 1984, pp. 6369 (in Russian).

3. Lyakhovich L.S., Maletkin O.Yu. O Pricel'nom Regulirovanii Sobstvennyh Chastot Uprugih Sistem [A bout Aimed
Control of Natural Frequencies of Elastic Systems]. // Izvestia Vuzov. Construction and A rchitecture, 1990, No. 1, pp. 113-117 (in Russian).

4. Lyakhovich L.S. Osobye Svojstva Optimal'nyh Sistem i Osnovnye Napravlenija ih Realizacii v M etodah Rascheta Sooruzhenij [Special Properties of Optimal Systems and the $M$ ain Directions of Their Implementation in the M ethods of Calculation of Structures]. Tomsk, Tomsk State University of A rchitecture and Construction, 2009, 372 pages (in Russian).

5. L yakhovich L.S., Akimov P.A. Aimed control of the frequency spectrum of eigenvibrations of elastic plates with a finite number of degrees of freedom of masses by superimposing additional constraints. // International Journal for Computational Civil and Structural Engineering, 2021, V olume 17, Issue 2, pp. 76-82. 
6. Lyakhovich L.S., A kimov P.A., Tukhfatullin B.A. A ssessment of the proximity of design to minimum material capacity solution of problem of optimization of the flange width of I-shaped cross-section rods with allowance for stability constraints or constraints for the value of the first natural frequency and strength requirements. // International J ournal for Computational Civil and Structural Engineering, 2021, V olume 16, Issue 2, pp. 71-82.

\section{СПИСОК ЛИТЕРАТУРЫ}

1. Нудельман Я.Л., Ляхович Л.С., Гитерман Д.М. О наиболее податливых связях наибольшей жесткости. // Вопросы прикладной механики и математики, Томск, Издательство ТГУ, 1981, с. 113126.

2. Гитерман Д.М., Ляхович Л.С., Нудельман Я.Л. Алгоритм создания резонансно-безопасных зон при помощи наложения дополнительных связей. // Динамика и прочность машин, Вып. 39, Харьков, «Вища школа», 1984, с. 63-69.

3. Ляхович Л.С., Малеткин О.Ю. О прицельном регулировании собственных ча- стот упругих систем. // Известия вузов. Строительство и архитектура, 1990, №1, c. 113-117.

4. Ляхович Л.С. Особые свойства оптимальных систем и основные направления их реализации в методах расчета сооружений. Томск: Издательство Томского государственного архитектурностроительного университета, 2009. $372 \mathrm{c}$.

5. Lyakhovich L.S., Akimov P.A. Aimed control of the frequency spectrum of eigenvibrations of elastic plates with a finite number of degrees of freedom of masses by superimposing additional constraints. // International J ournal for Computational Civil and Structural Engineering, 2021, V olume 17, Issue 2, pp. 76-82.

6. Lyakhovich L.S., Akimov P.A., Tukhfatullin B.A. A ssessment of the proximity of design to minimum material capacity solution of problem of optimization of the flange width of I-shaped cross-section rods with allowance for stability constraints or constraints for the value of the first natural frequency and strength requirements. // International J ournal for Computational Civil and Structural Engineering, 2021, V olume 16, Issue 2, pp. 71-82.
Pavel A. Akimov, Full Member of the Russian A cademy of Architecture and Construction Sciences, Professor, Dr.Sc.; Rector of National Research M oscow State University of Civil Engineering; Professor of Department of Structural Mechanics, Tomsk State University of A rchitecture and Building; 24, UI. Bolshaya Dmitrovka, 107031, M oscow, Russia; phone +7(495) 625-71-63; Fax: +7 (495) 650-27-31; E-mail: akimov@raasn.ru, pavel.akimov@gmail.com.

Leonid S. Lyakhovich, Full M ember of the Russian A cademy of A rchitecture and Construction Sciences, Professor, DSc, Head of Department of Structural M echanics, Tomsk State University of Architecture and Building; 634003, Russia, Tomsk, Solyanaya St., 2; E-mail: 1ls@tsuab.ru
Акимов Павел Алексеевич, академик РААСН, професcop, доктор технических наук; ректор Национального исследовательского Московского государственного строительного университета; профессор кафедры строительной механики Томского государственного архитектурно-строительного университета; 107031, г. Москва, ул. Большая Дмитровка, д. 24, стр. 1; тел. +7(495) 625-71-63; факс +7 (495) 650-27-31; Email: akimov@raasn.ru,pavel.akimov@gmail.com.

Ляхович Леонид Семенович, академик РААСН, профессор, доктор технических наук, профессор кафедры строительной механики, Томский государственный архитектурно-строительный университет; 634003, Россия, г. Томск, Соляная пл. 2; E-mail: Ils@tsuab.ru 